\title{
Kinetics and Equilibrium Studies on Adsorption of Acid Red 18 (Azo-Dye) Using Multiwall Carbon Nanotubes (MWCNTs) from Aqueous Solution
}

\author{
MOHAMMAD SHIRMARDI ${ }^{1}$, ALIREZA MESDAGHINIA ${ }^{1}$, AMIR HOSSEIN \\ MAHVI $^{1,2,3^{*}}$, SIMIN NASSERI $^{1}$, AND RAMIN NABIZADEH $^{1}$
}

${ }^{1}$ School of Public Health, Tehran University of Medical Sciences, Tehran, Iran ${ }^{2}$ National Institute of Health Research, Tehran University of Medical Sciences, Tehran, Iran ${ }^{3}$ Center for Solid Waste Research, Institute for Environmental Research, Tehran University of Medical Sciences, Tehran, Iran

ahmahvi@yahoo.com

Received 12 August 2011; Accepted 04 October 2011

\begin{abstract}
Azo dyes are one of the synthetic dyes that are used in many textile industries. Adsorption is one of the most effective techniques for removal of dye-contaminated wastewater. In this work, efficiency of multiwalled carbon nanotubes (MWCNTs) as an adsorbent for removal of Acid Red 18 (azo-dye) from aqueous solution was determined. The parameters affecting the adsorption process such as contact time, $\mathrm{pH}$, adsorbent dosage, and initial dye concentration were studied. Experimental results have shown by increasing the adsorbent dosage, the rate of dye removal was increased, but the amount of adsorbed dyes per mass unit of MWCNTs was declined. $\mathrm{pH}$ as one of the most important influencing factors on the adsorption process was evaluated. The best $\mathrm{pH}$ for adsorption process was acidic $\mathrm{pH}$ of about 3 . To describe the equilibrium of adsorption, the Langmuir, Freundlich and Temkin isotherms were used. The Langmuir isotherm $\left(\mathrm{R}^{2}=0.985\right)$ was the best fitted for experimental data with maximum adsorption capacity of $166.67 \mathrm{mg} / \mathrm{g}$. A higher correlation value of the kinetic's model was observed close to pseudo second order $\left(\mathrm{R}^{2}=0.999\right)$ compared to other kinetic models.
\end{abstract}

Keywords: Adsorption, Acid Red 18 (azo dye), MWCNTs, Kinetics and Equilibrium.

\section{Introduction}

There are more than 1,00,000 types of dyes commercially available, with over $7 \times 10^{5}$ tonnes of dyestuff produced annually, which can be classified according to their structure as anionic and cationic ${ }^{1}$. The treatment and disposal of dye-contaminated wastewater is one of the most serious environmental problems faced by the textile, dyeing, printing, ink and related industries $^{2}$.Azo dyes are one of the synthetic dyes that used in many textile industries. Azo dyes and their intermediate products are toxic, carcinogenic and mutagenic to aquatic life ${ }^{3}$. Many treatment methods have been adopted to remove dyes from wastewater, which can be divided into physical, chemical and biological methods ${ }^{4}$. Moreover, in order to treat 
wastewater dyes, many researchers have been investigated the effect of advanced oxidation processes (AOPs). Applicable example of this technology can be expressed as decolorization and degradation of dyes by photocatalytic and nanophotocatalytic processes ${ }^{5-7}$.

Among the advanced chemical and physical treatment processes, adsorption is considered to be superior to other techniques. This is attributed to its easy availability, simplicity of design, ease of operation, biodegradability, insensitivity to toxic substances and ability to treat dyes in more concentrated forms. Physical adsorption has been proven to be the most efficient method for quickly lowering the concentration of dissolved dyes in an effluen $^{\mathrm{t} 8,9}$. Carbon nanotubes (CNTs) are an attractive alternative in removal of organic and inorganic contaminants such as heavy metal, trihalomethanes (THMs), fluoride and dyes from water and wastewater ${ }^{10-14}$, because of their small sizes, large surface areas, unique hollow structures, high mechanical strength and remarkable electrical conductivities ${ }^{15-17}$. In this study, the adsorption behavior of multiwalled carbon nanotubes (MWCNTs), its removal capacity and other adsorption condition of an azo dye such as AR18 from aquatic solution have been investigated. The influence of contact time, $\mathrm{pH}$, adsorbent dosage and initial dye concentration was studied. Furthermore, in order to find out the relation between adsorbent and adsorbed AR18, the isotherm and kinetics of adsorption were evaluated.

\section{Experimental}

All reagent and material were obtained in laboratory grade (Merck, Germany).

\section{Characterization of MWCNTs}

The MWCNTs being synthesized in the Iranian Research Institute of Petroleum Industry (RIPI), was purchased and was used without any purification for this study. The purity of MWCNTs was more than $95 \%$. Table 1 presents the characteristics of prepared multiwalled carbon nanotubes. These nanotubes were synthesized by using chemical vapor deposition (CVD) of hydrocarbons. Furthermore, the size and morphology of MWCNTs were characterized by scanning electron microscope (SEM) and transmission electron microscopy (TEM) using a Philips XL 30 ESEM). Figure 1 and 2 shows the TEM and SEM images of MWCNT S. $_{\text {. }}$

Table 1. The characteristics of MWCNTs.

\begin{tabular}{ccc}
\hline characteristic & value & unit \\
\hline Specific surface area (BET) & 270 & $\mathrm{~m}^{2} / \mathrm{g}$ \\
Length & 10 & $\mu \mathrm{m}$ \\
Diameter & $10-30$ & $\mathrm{~nm}$ \\
Thermal conductivity & 1500 & $\mathrm{w} / \mathrm{mV}$ \\
\hline
\end{tabular}

\section{Adsorbate}

Since AR18 has an azo group band $(-\mathrm{N}=\mathrm{N}-)$, then it is in the group of azo dyes. The molecular structure of AR18 is shows in Figure 3, which is provided by Merck Company (Germany). Molar mass of AR18 is $604.47 \mathrm{~g} \mathrm{~mol}^{-1}$ with molecular formula of $\mathrm{C}_{20} \mathrm{H}_{11} \mathrm{~N}_{2} \mathrm{Na}_{3} \mathrm{O}_{10} \mathrm{~S}_{3}$. The AR18 dye was made with high purity of dye and was applied without further purification. The dye stock solution was prepared by dissolving $500 \mathrm{mg}$ of acid red 18 (AR18) in $1000 \mathrm{~mL}$ deionized water. The lesser concentrations of dye was fabricated with dilution of stock dye. 

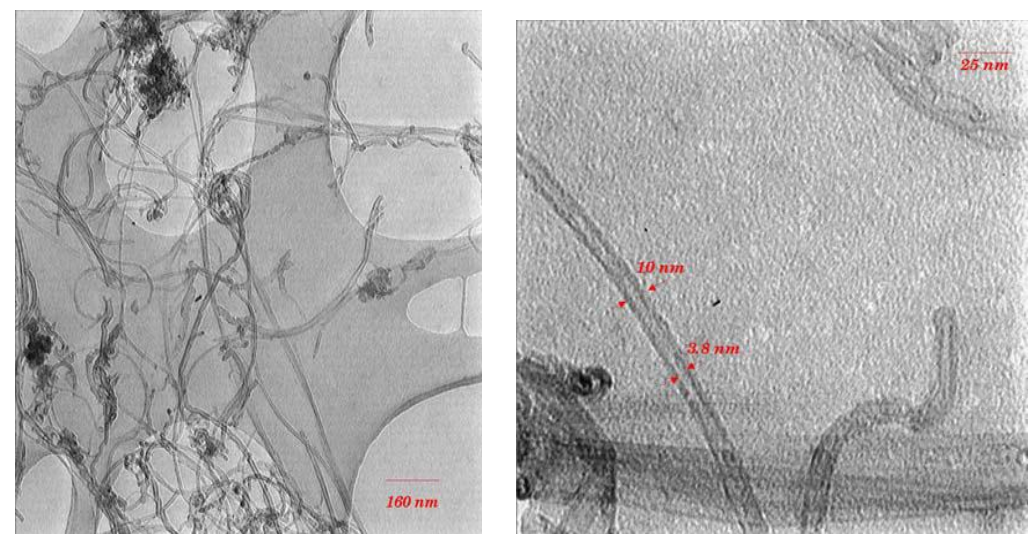

Figure 1. TEM of MWCNTs.

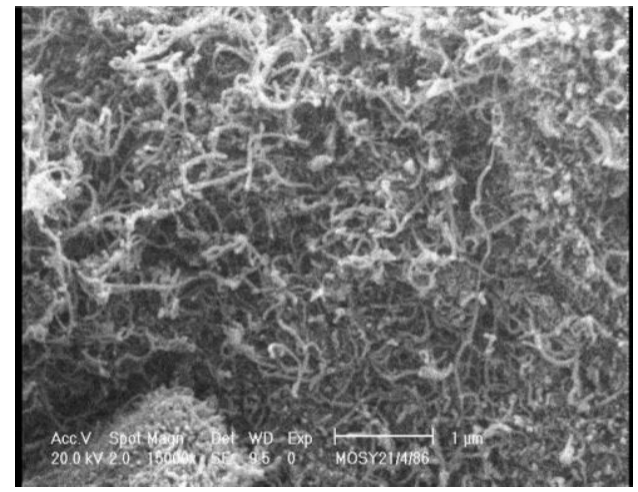

Figure 2. SEM of MWCNTs.<smiles>CS(=O)(=O)c1cc(S(=O)(=O)O)c2c(/N=N/c3ccc(S(=O)(=O)O)c4ccccc34)c(O)ccc2c1</smiles>

Figure 3. Structure of the azo dye Acid Red 18.

\section{Batch Adsorption Experiments}

In order to contact between adsorbent and dye solution, all tests were conducted in a closed Erlenmeyer flasks with $250 \mathrm{~mL}$ capacity as a batch system. Different doses of MWCNTs were applied by adding $0.02,0.04$, and $0.06 \mathrm{~g}$ of adsorbent per $100 \mathrm{~mL}$ of dye solution. Furthermore, the $\mathrm{pH}$ was adjusted to the desired value with $1 \mathrm{~N} \mathrm{HCl}$ and $\mathrm{NaOH}$ (Merck, Germany). In this study, various parameters such as contact time ranges from (5-240 minute), pH 3 to 9 , adsorbent dosage $(0.2,0.4,0.6 \mathrm{~g} / \mathrm{L})$, initial dye concentrations $(25,50,75$, and 
$100 \mathrm{mg} / \mathrm{L}$ ) were investigated in different experiments. In all experiments, the temperature was kept constant $\left(25^{\circ} \mathrm{C}\right)$. For better mixing, the Erlenmeyer flasks which contain $100 \mathrm{mg} / \mathrm{L}$ of dye solution were placed in the illuminated refrigerated incubator shaker (Innova 4340, USA) and were agitated at $175 \mathrm{rpm}$. At the end of equilibrium time the suspensions were centrifuged for $10 \mathrm{~min}$ at $4000 \mathrm{rpm}$ and then the supernatant of suspension was filtered using a $0.2 \mu \mathrm{m}$ Millipore filter. The final dye concentrations (AR18) were evaluated by UV-visible spectrophotometer (Lambda 25, USA) at maximum wavelength $(506 \mathrm{~nm})$. After taking these measurements, the concentrations of residual dye were determined by calibration curves. Removal efficiency, adsorption capacity (q) and Distribution coefficients were calculated using the following equations ${ }^{19}$ :

$$
\begin{gathered}
\text { Removal efficiency } \%=\frac{\left(\mathrm{C}_{\mathrm{o}}-\mathrm{C}_{\mathrm{f}}\right)}{\mathrm{C}_{\mathrm{o}}} X 100 \\
\mathrm{q}=\frac{\left(C_{o}-C_{\mathrm{f}}\right) \mathrm{X} \mathrm{V}}{M}
\end{gathered}
$$

\section{Isotherm Analysis}

For analyzing the experimental data, adsorption isotherm models were used to determine the homogeneous and heterogeneous characteristics. To evaluate the adsorption isotherm, three equilibrium isotherms were studied: (A) Langmuir, (B) Freundlich, and (C) Temkin. Analysis of isotherms was used to describe the experimental adsorption data, and then best results can be obtained when correlation coefficients $\left(R^{2}\right)$ come close to 1 . High values of $R^{2}$ (close or equal to 1) indicate the conformity among experimental data with model isotherm or kinetic. The equations of these three isotherms and their linear forms are as below:

A- Langmuir equation:

$$
\mathrm{q}_{\mathrm{e}}=\frac{\mathrm{q}_{\mathrm{m}} \mathrm{K}_{\mathrm{c}} \mathrm{C}_{\mathrm{e}}}{1+\mathrm{K}_{\mathrm{c}} \mathrm{C}_{\mathrm{e}}}
$$

First, the Langmuir isotherm was used in order to describe the equilibrium of gas molecules onto the metal surface ${ }^{18}$. The linear form of Langmuir equation is expressed as the following Eq. (4):

$$
\frac{\mathrm{C}_{\mathrm{e}}}{\mathrm{q}_{\mathrm{e}}}=\frac{1}{K_{c} q_{m}}+\frac{\mathrm{C}_{\mathrm{e}}}{\mathrm{q}_{\mathrm{m}}}
$$

B- Freundlich equation:

$$
\mathrm{q}_{\mathrm{e}}=\mathrm{K}_{\mathrm{f}} \mathrm{C}^{1 / \mathrm{n}}
$$

Freundlich In 1906 presented his isotherm as an empirical model, which later was known with his name. This model can be applied to non ideal sorption on heterogeneous surfaces as well as multilayer sorption ${ }^{20}$. Linearizing the Freundlich equation Eq. (6) gives:

$$
\log q_{e}=\log \left(K_{F}\right)+1 / n \log \left(C_{e}\right)
$$


C- Temkin equation:

$$
q_{e}=B_{1} \ln \left(k_{t} C_{e}\right)
$$

Temkin isotherm contains a factor that explicitly takes into the account the adsorptiveadsorbent interactions ${ }^{21}$. Linearizing the Temkin equation Eq. (8) gives:

$$
q_{e}=B_{1} \ln k_{t}+B_{1} \ln C_{e}
$$

\section{Kinetic Analysis}

In order to investigate the capacity of dye mass transfer ${ }^{22}$ to MWCNTs sites, kinetics of adsorption was evaluated. The analysis of the isotherm data is important to develop an equation which accurately represents the results and could be used for design purposes ${ }^{23}$. Therefore, in this paper, three models of kinetic for 50 and $100 \mathrm{mg} / \mathrm{L}$ of dye were studied. These models are such as: (A) pseudo first-order, (B) pseudo second-order, (C) WeberMorris (or intraparticle diffusion). The models of kinetic and their applied forms are as following equations:

A- Pseudo first-order Equation:

$$
\frac{d q_{t}}{d t}=k_{1}\left(q_{e}-q_{t}\right)
$$

The linearized Pseudo first-order equation is given as:

$$
\log \left(\mathrm{q}_{\mathrm{e}}-\mathrm{q}_{\mathrm{t}}\right)=\log \left(\mathrm{q}_{\mathrm{e}}\right)-\frac{\mathrm{k}_{1}}{2.303} t
$$

B- Pseudo second-order Equation:

$$
\frac{d q_{t}}{d t}=k_{2}\left(q_{e}-q_{t}\right)^{2}
$$

The linearized Pseudo second-order equation is given as:

$$
\frac{t}{q_{t}}=\frac{1}{h}+\frac{1}{q_{e}} t
$$

C- Weber-Morris Equation;

$$
\mathrm{q}_{\mathrm{t}}=\mathrm{k}_{\mathrm{id}}(\mathrm{t})^{\mathrm{a}}+C
$$

The linearized Weber-Morris Equation is given as:

$$
\log \mathrm{q}_{\mathrm{t}}=\log \mathrm{k}_{\mathrm{id}}+\operatorname{alog}(\mathrm{t})
$$




\section{Results and Discussion}

\section{Effect of Contact Time}

To evaluate the effect of contact time on adsorption process, minimal dose of adsorbent was selected and was added to different dye concentrations $(25,50,75,100) . \mathrm{pH}$ of solutions was adjusted to 5 that was much close $\mathrm{pH}$ to the actual $\mathrm{pH}$ of solutions. Solutions were placed in the illuminated refrigerated incubator shaker (Innova 4340, USA) and the samples were taken at different time intervals. The effect of contact time on adsorption of dye is shown on Figure 4. As shown in Figure 4 adsorption of dye was increased by increasing the contact time. The adsorption process was faster in the initial $30 \mathrm{~min}$ and then became slowly until reached to equilibrium at 120 minutes. For investigation of other parameters, the equilibrium time was used .

\section{Effect of $p H$}

The effect of $\mathrm{pH}$ on the adsorption process by MWCNTs was evaluated by different value of initial $\mathrm{pH}$. As shown on Figure 5, different $\mathrm{pH}$ condition in four ranges of 3, 5, 7, and 9 were applied for the initial concentrations of $25,50,75$, and $100 \mathrm{mg} / \mathrm{L}$. Higher efficiency of dye adsorption observed at acidic $\mathrm{pH}$ of 3 for any concentration of dye, while a decrease in adsorption rate was occurred with an increase in $\mathrm{pH}$ from acidic to neutral and alkaline ranges. In low $\mathrm{pH}$, the surface of carbon material was charged with $\mathrm{H}^{+}$ion and this leads to a significantly strong electrostatic attraction between the positively charged carbon surface and anionic dye molecules which caused an increasing rate in dye sorption ${ }^{24}$. Furthermore, initial dye concentration affected the adsorption efficiency. Maximum adsorptions obtained with different concentrations of $25,50,75$, and $100 \mathrm{mg} / \mathrm{L}$ at $\mathrm{pH} 3$ equal to $98.71 \%, 96.97 \%$, $78.79 \%$, and $66.97 \%$, respectively.

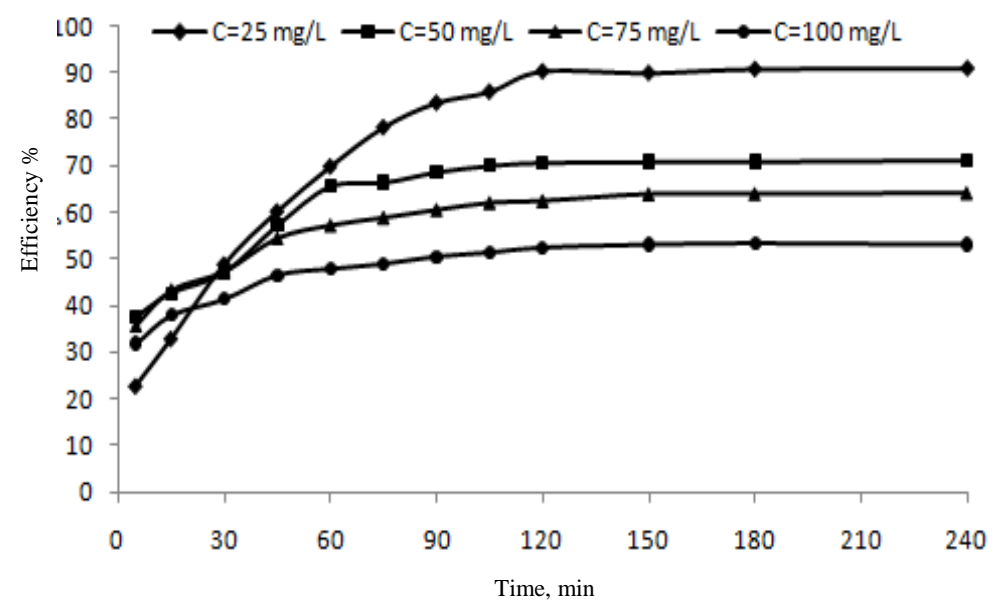

Figure 4 Effect of contact time on adsorption of AR18 to MWCNTs in different dye concentrations $\left(\mathrm{pH}=5, \mathrm{MWCNTs}=0.2 \mathrm{~g} / \mathrm{L}, \mathrm{T}=25^{\circ} \mathrm{C}\right)$. 


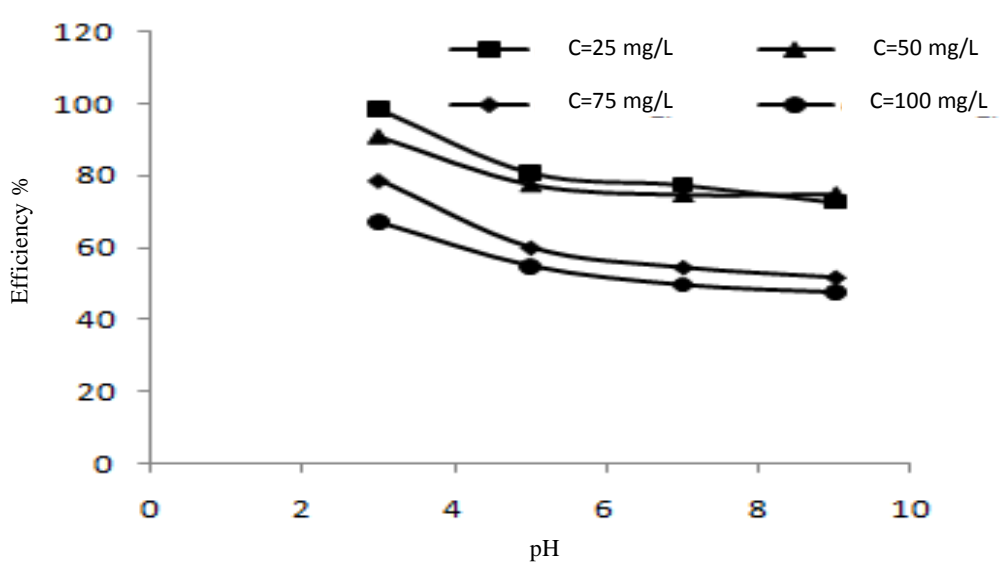

Figure 5. Effect of $\mathrm{pH}$ on the adsorption of AR18 onto MWCNTs in different dye concentration (adsorbent dosage $=0.04 \mathrm{~g} / 100 \mathrm{~mL}$, contact time $=120 \mathrm{~min}, \mathrm{~T}=25^{\circ} \mathrm{C}$ ).

\section{Effect of Adsorbent Dosage}

Figure 6. shows the effect of MWCNTs dosage on the adsorption process. In order to find the optimum dosage of MWCNTs, three doses of adsorbent were investigated. The tests were performed at equilibrium time of $120 \mathrm{~min}$ and $\mathrm{pH} 3$. Highest adsorption rate was obtained in $0.06 \mathrm{~g}$ of MWCNTs. An increase in adsorption rate with adsorbent dosage can be attributed to increased surface area and the availability of more adsorption sites ${ }^{25}$. For kinetics and equilibrium studies the mean dosage $(0.4 \mathrm{~g})$ of MWCNTs was selected as the optimum dose.

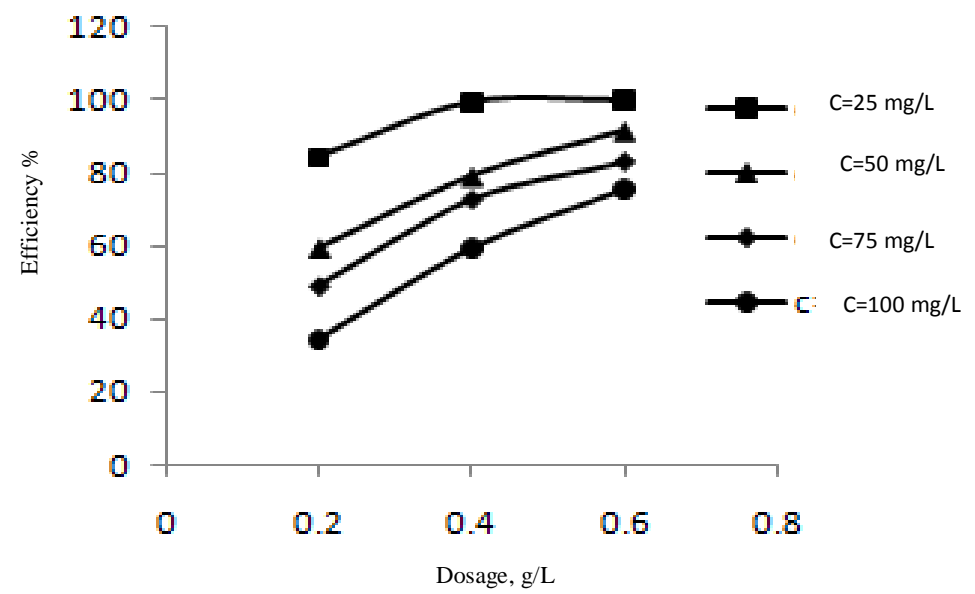

Figure 6. Effect of adsorbent dosage on the adsorption of AR18 in different dye concentration (contact time $=120 \mathrm{~min}, \mathrm{pH}=3, \mathrm{~T}=25^{\circ} \mathrm{C}$ ).

\section{Effect of Initial Dye Concentration}

The influence of initial dye concentration on adsorption of AR18 onto MWCNTs was investigated by adding of $0.04 \mathrm{~g}$ of MWCNTs to $100 \mathrm{~mL}$ of dye solution and contact time equal to equilibrium time $(120 \mathrm{~min})$. As shown in Figure 7 by increasing the initial dye 
concentration, the adsorption of AR18 was decreased. The adsorption of dye was faster at initial stages and gradually decreased and became constant after equilibrium was reached. For constant dosage of adsorbent at lower initial dye concentration the large number of vacant surface sites was available for adsorption of dye. Mean while, by increase of dye concentration, adsorption sites of adsorbent became lower and due to repulsive forces between dyes molecules on $\mathrm{MWCNT}_{\mathrm{S}}$, the occupation of remaining vacant surface sites were difficult. Removal of AR18 onto $\mathrm{MWCNT}_{\mathrm{S}}$ is dependent on initial dye concentration, at an initial concentration of $25 \mathrm{mg} / \mathrm{L}$ of AR18 and maximum removal efficiency was found to be $(98.2 \%)$ and by increasing the AR18 concentration to $100 \mathrm{mg} / \mathrm{L}$, the removal efficiency decreased to (63.8\%). However, the amount of adsorbed AR18 per unit of $\mathrm{MWCNT}_{\mathrm{S}}$ mass increased from 61.38 to $159.5 \mathrm{mg} / \mathrm{g}$. Therefore, the increase in initial dye concentration resulted in increase of the driving force for mass transfer.

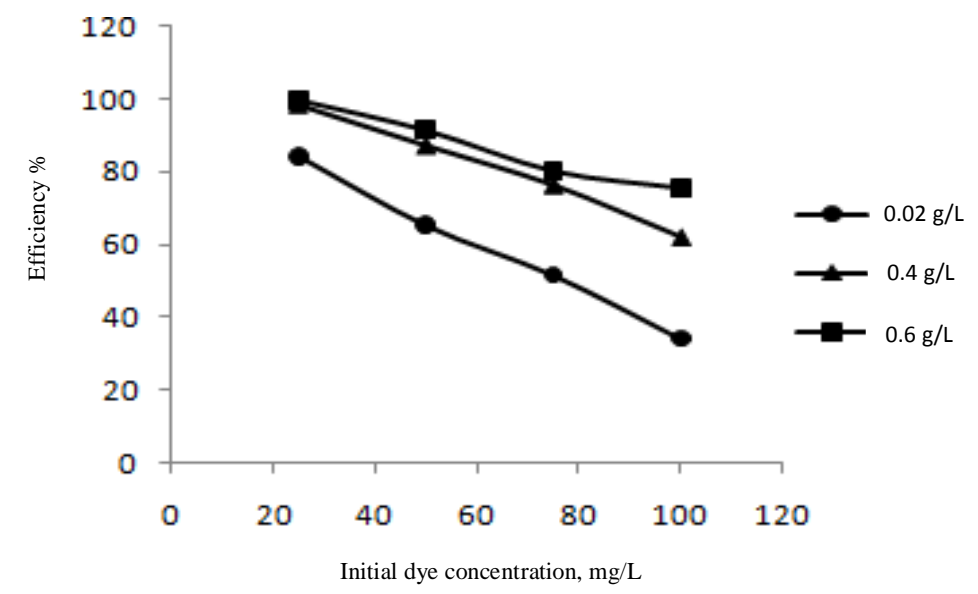

Figure 7. Effect of initial dye concentration on adsorption of AR18 onto $\mathrm{MWCNT}_{\mathrm{S}}$ (contact time $=120 \mathrm{~min}, \mathrm{pH}=3, \mathrm{~T}=25^{\circ} \mathrm{C}$ ).

\section{Adsorption Isotherms}

In this study, various isotherm models such as Langmuir, Freundlich, and Temkin were studied to describe the equilibrium characteristics of adsorption. Isotherm is the relationship between the equilibrium amount of dye (AR18) adsorbed on MWCNTs surface and residual concentration of dye in solution. Figure 8 illustrates Langmuir isotherm plot for experimental data $\left(\mathrm{q}_{\mathrm{e}} / \mathrm{C}_{\mathrm{e}}\right.$ vs. $\left.\mathrm{C}_{\mathrm{e}}\right)$. Referring to Table $2, \mathrm{R}^{2}$ value in this model is 0.985 . Freundlich plot presented in Figure 9, has been drawn with $\log \mathrm{q}_{\mathrm{e}} v s$. $\log \mathrm{C}_{\mathrm{e}} \mathrm{R}^{2}$ value of Freundlich isotherm was determined to be 0.971. Furthermore, in Figure 10, Temkin isotherms plot $\left(\mathrm{Ln} \mathrm{C}_{\mathrm{e}} v s . \mathrm{C}_{\mathrm{e}}\right.$ ) with $\mathrm{R}^{2}=0.982$ is illustrated. In contrast, it can be found that the Langmuir isotherm with $\mathrm{R}^{2}=0.985$ represents the best fit with the adsorption experimental data, and adsorption data of dye onto MWCNTs are confirmed with this model related to former models. Further detail of isotherms models are given in Table 2.

Table 3 illustrated the maximum adsorption capacity of some adsorbents that have been published on literature for various dyes in different conditions. According to this table CNTs have higher efficiency comparative to other adsorbent. But, due to variable experimental condition a direct comparison between different adsorbents cannot be made.

It is worth to mention that application of different enzymes has shown a good promise in removal of dyes from textile wastewaters and are as well as adsorption processes using $\mathrm{MWCNT}_{\mathrm{s}}^{36}$. 


\section{Kinetic Models}

In this study, to express the mechanism of AR18 adsorption onto MWCNTs, the most three popular kinetic models were used. These models are Pseudo first order, Pseudo second order and Weber-Morris. The experimental data was obtained for two concentrations of 50, $100 \mathrm{mg} / \mathrm{L}$, at equilibrium time $120 \mathrm{~min}$, MWCNTs dosage $0.04 \mathrm{~g}$ and $\mathrm{pH}$ 7. The plots of kinetic models are presented in Figures 11-13. With regard to the plots of these models and with the help of Table 3, it can be seen, that higher $\mathrm{R}^{2}$ has been achieved in Pseudo second order. With regard to pseudo second order $\mathrm{R}^{2}$ value $(0.999)$ for the concentrations of 50 , and $100 \mathrm{mg} / \mathrm{L}$, it can be seen that it is the best fit conformity in this model. Therefore, adsorption mechanism of AR18 was close to second order model and it is suggested for dye adsorption onto multiwall carbon nanotubes surface. Kinetic details of AR18 adsorption with the correlation coefficients are presented in Table 4.

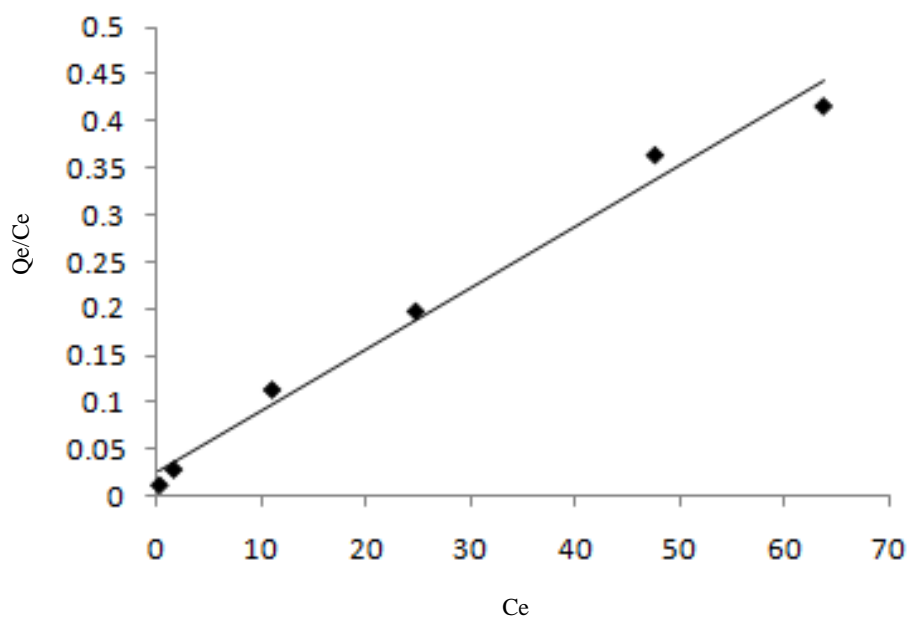

Figure 8. Langmuir isotherm for adsorption data of AR18 by MWCNTs; Time $120 \mathrm{~min}$, dose: $0.04 \mathrm{~g} / 100 \mathrm{~mL}, \mathrm{pH}=7$.

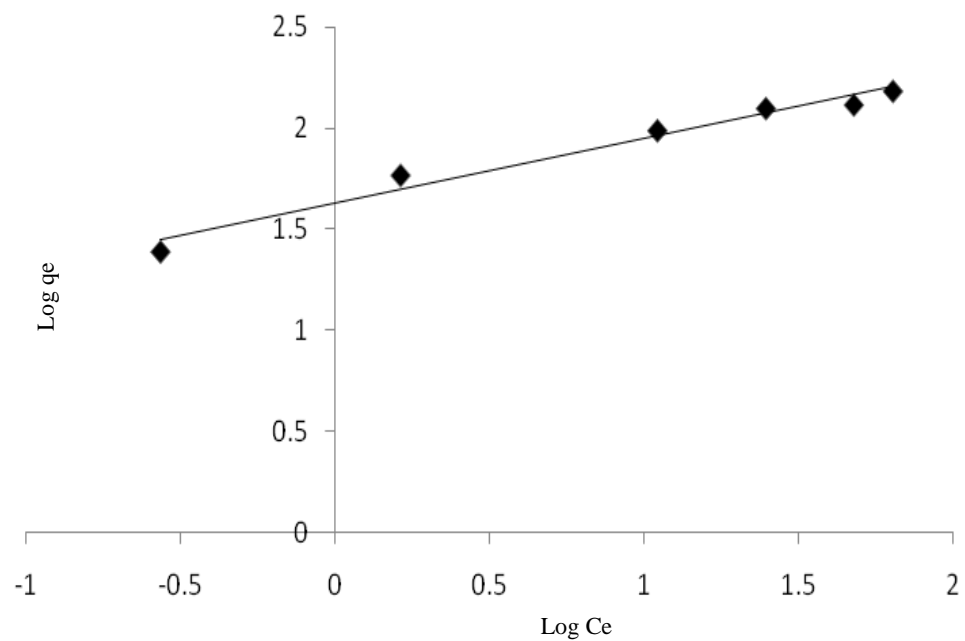

Figure 9. Freundlich isotherm for adsorption data of AR18 by MWCNTs; Time 120 min, dose: $0.04 \mathrm{~g} / 100 \mathrm{~mL}, \mathrm{pH}=7$. 


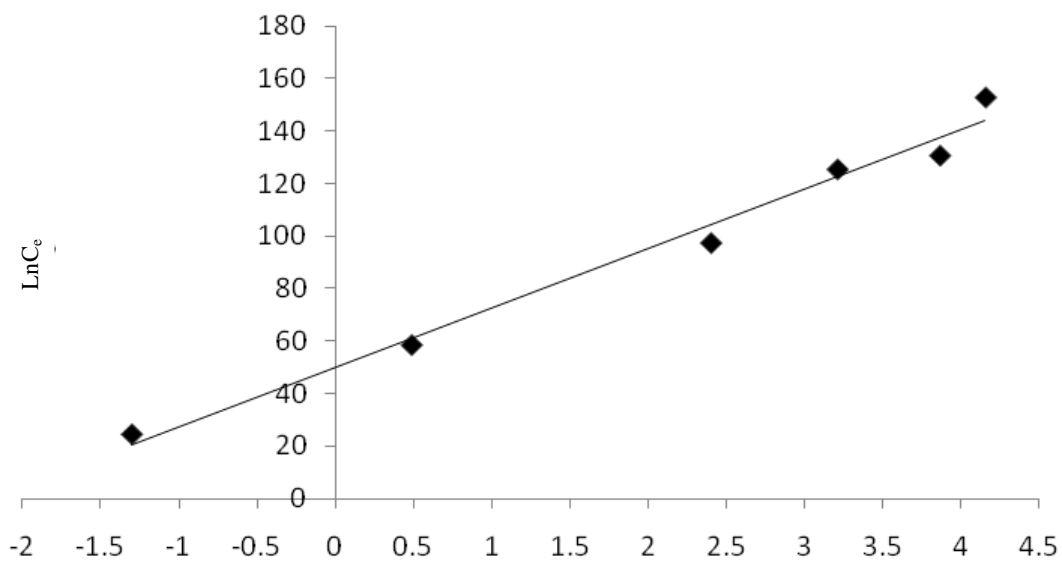

$\mathrm{q}_{\mathrm{e}}$

Figure 10. Temkin isotherm for adsorption data of AR18 by MWCNTs; Time $120 \mathrm{~min}$, dose: $0.04 \mathrm{~g} / 100 \mathrm{~mL}, \mathrm{pH}=7$.

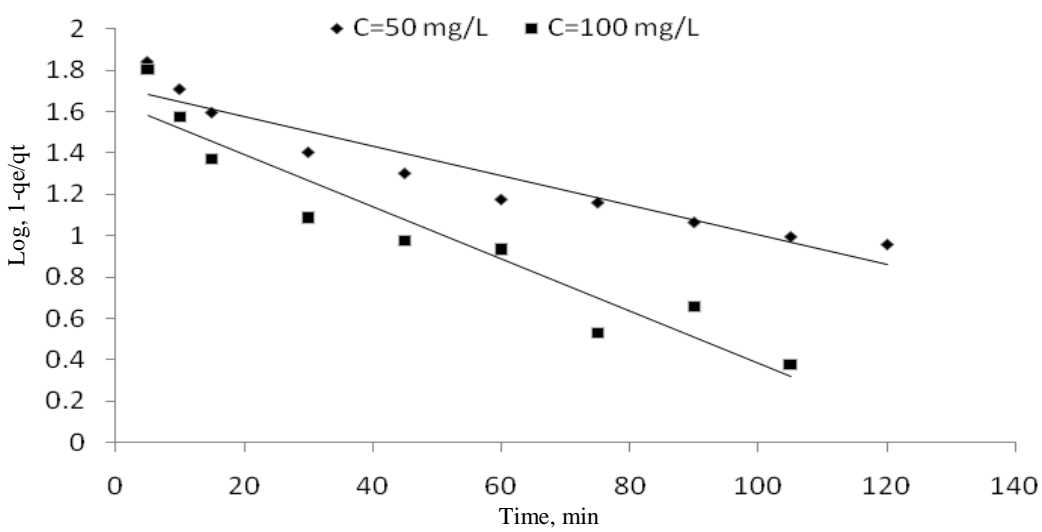

Figure 11. Pseudo-first order kinetic model; Time 120 min, dose: 0.04 g/100 ml, pH 7.

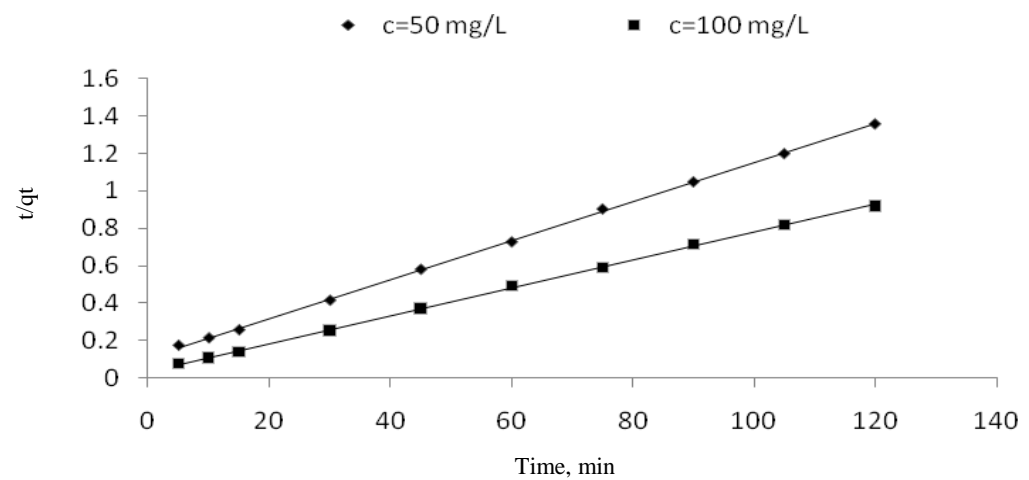

Figure 12. Pseudo-second order kinetic model; Time 120 min, dose: 0.04 g/100 mL, pH 7. 


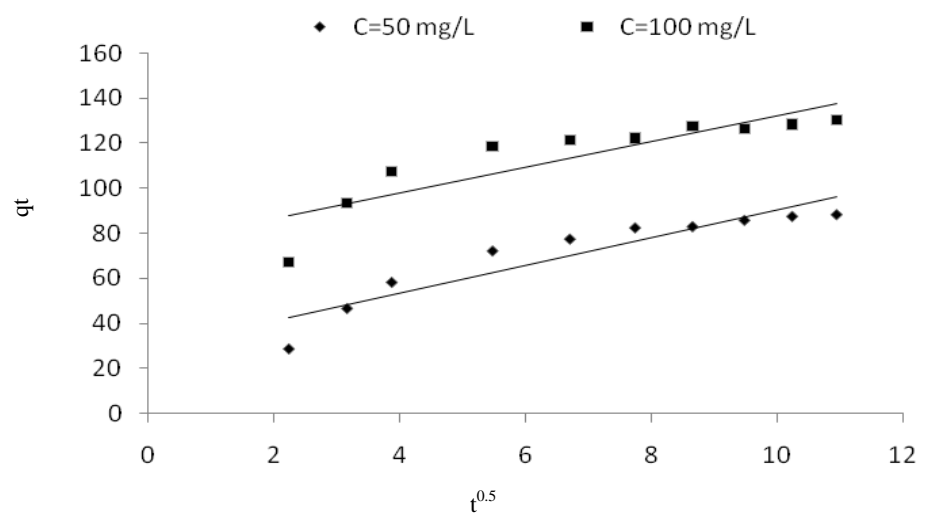

Figure 13. Weber-Morris kinetic model; Time 120 min, dose: 0.04 g/100 mL, pH 7.

Table 3. Maximum adsorption capacity of some adsorbents for different dyes.

\begin{tabular}{|c|c|c|c|c|}
\hline Adsorbent & Adsorbate & Conditions & $\begin{array}{c}\text { Maximum } \\
\text { adsorption } \\
\text { capacity, mg/g }\end{array}$ & References \\
\hline \multirow[t]{2}{*}{$\mathrm{MWCNT}_{\mathrm{S}}$} & Acid Red 18 & - & 166.67 & Present work \\
\hline & & $290^{\circ} \mathrm{k}$ & 103.62 & \\
\hline \multirow[t]{2}{*}{$\mathrm{MWCNT}_{\mathrm{S}}$} & Methylene Blue & $300^{\circ} \mathrm{k}$ & 109.31 & [26] \\
\hline & & $310^{\circ} \mathrm{k}$ & 119.71 & \\
\hline \multirow{3}{*}{$\mathrm{F}^{-\mathrm{MWCNT}_{\mathrm{S}}}$} & Direct Gongo Red & - & 148 & \multirow{3}{*}{ [27] } \\
\hline & $\begin{array}{l}\text { Reactive Green } \\
\text { HI-4BD }\end{array}$ & - & 152 & \\
\hline & Golden Yellow & - & 141 & \\
\hline \multirow{2}{*}{$\mathrm{MWCNT}_{\mathrm{s}}-\mathrm{Fe}_{2} \mathrm{O}_{3}$} & Methylene Blue & - & 42.3 & \multirow{2}{*}{ [28] } \\
\hline & Neutral Red & - & 77.5 & \\
\hline $\mathrm{CNT}_{\mathrm{S}}$ & $\begin{array}{c}\text { Procion Red } \\
\text { MX-5B }\end{array}$ & $\begin{array}{c}301{ }^{\circ} \mathrm{k} \\
\mathrm{PH}=6.5\end{array}$ & 39.84 & [29] \\
\hline \multirow{2}{*}{$\begin{array}{l}\text { Halloysite } \\
\text { nanotubes }\end{array}$} & \multirow{2}{*}{ Neutral Red } & $298^{\circ} \mathrm{k}$ & 54.85 & \multirow{2}{*}[30]{} \\
\hline & & $308^{\circ} \mathrm{k}$ & 59.24 & \\
\hline Activated carbon & Acid Red 97 & - & 82.08 & {$[31]$} \\
\hline \multirow[t]{2}{*}{$\begin{array}{l}\text { Activated carbon } \\
\text { (poplar wood) }\end{array}$} & Acid Red 18 & - & 3.9 & {$[3]$} \\
\hline & & $298^{\circ} \mathrm{k}$ & 40.06 & \\
\hline \multirow[t]{2}{*}{ Activated carbon } & Methylene Blue & $303^{\circ} \mathrm{k}$ & 40.38 & {$[32]$} \\
\hline & & $318^{\circ} \mathrm{k}$ & 42.86 & \\
\hline $\begin{array}{l}\text { Activated rice } \\
\text { husk carbon }\end{array}$ & Acid yellow 36 & - & 86.9 & [33] \\
\hline $\begin{array}{c}\text { Commercial } \\
\text { activated carbon }\end{array}$ & Acid yellow 23 & - & 56.5 & [34] \\
\hline Activated carbon & Reactive Yellow 15 & - & 116 & {$[35]$} \\
\hline Eggshell & Reactive Red 123 & - & 1.26 & [19] \\
\hline
\end{tabular}


Table 4. Kinetic details of AR18 adsorption by MWCNTs.

\begin{tabular}{ccccc}
\hline Kinetic model & Parameters & $\begin{array}{c}\text { Pseudo-first } \\
\text { order }\end{array}$ & $\begin{array}{c}\text { Pseudo second } \\
\text { order }\end{array}$ & $\begin{array}{c}\text { Weber- } \\
\text { Morriss }\end{array}$ \\
\hline Conc. & $\mathrm{R}^{2}$ & 0.915 & 0.999 & 0.864 \\
$(50 \mathrm{Mg} / \mathrm{L})$ & Constant & $\mathrm{k}_{1}=0.016$ & $\mathrm{k}_{2}=0.093$ & $\mathrm{k}_{\text {id }}=6.10$ \\
& $\mathrm{q}_{\mathrm{e}}$ & 51.88 & 100 & - \\
Conc. & $\mathrm{R}^{2}$ & 0.914 & 0.999 & 0.764 \\
$(100 \mathrm{mg} / \mathrm{L})$ & Constant & $\mathrm{k}_{1}=0.0009$ & $\mathrm{k}_{2}=0.0015$ & $\mathrm{k}_{\mathrm{id}}=5.70$ \\
& $\mathrm{q}_{\mathrm{e}}$ & 43.95 & 142.8 & - \\
\hline
\end{tabular}

\section{Conclusion}

Dyes are one of the most-used materials in many industries. Azo dyes are toxic and carcinogenic to human and aquatic life. Therefore, these effluents should be treated prior to discharge. Adsorption process is considered, due to its easy availability, simplicity of design and other advantages. This study expressed a high-efficiency adsorbent for dye removal. MWCNTs as an adsorbent with high adsorption rate can be used for removal of Azo-dye from textile wastewaters. Using MWCNTs as a modern adsorbent can result in maximum adsorption capacity of AR18 to $166.67 \mathrm{mg} / \mathrm{g}$. Dye adsorption using MWCNTs will follow the Langmuir isotherm and pseudo second order kinetic model.

\section{Reference}

1. Robinson T, McMullan G. Marchant R and Nigam P, Bio Resour Technol., 2001, 77, 247-255.

2. Wang S, Boyjoo Y, Choueib A and Zhu Z H, Water Res., 2005, 39, 129-138.

3. Shokoohi R, Vatanpoor V, Zarrabi M and Vatani A, E-J Chem., 2010, 7(1), 65-72.

4. Vandevivere P C, Bianchi R. and Verstraete W, J Chem Technol Biotechnol., 1998, 72, 289-302.

5. Jeni J and Kanmani S, Iran J Environ Health Sci Eng., 2011, 8(1), 15-24.

6. Ehrampoush M H, Moussavi GH R, Ghaneian M T, Rahimi S and Ahmadian M., Iran J Environ Health Sci Eng., 2011, 8(1), 35-40.

7. Mahvi A H, Ghanbarian M, Nasseri S and Khairi A, Desalination, 2009, 239, 309-316.

8. Demirbas A, J Hazard Mater., 2009, 167, 1-9.

9. Luo X and Zhang L, J Hazard Mater., 2009,171, 340-347.

10. Peng X, Luan Z, Di Z, Zhang Z and Zhu C, Carbon, 2005, 43, 880-883.

11. Di Z C, Ding J, Peng X J, Li Y H, Luan Z K. and Liang J, Chemosphere, 2006, 62, 861-865.

12. Lu C S, Chung Y L and Chang K F, Adsorption Water Res., 2005, 39, 1183-1189.

13. Li Y H, Wang S, Zhang X, Wei J, Xu C, Luan Z and Wu D, Mater Res Bull., 2003, 38, 469-476.

14. Wu C H, Adsorption Hazard. Mater., 2007, 144, 93-100.

15. Barbusiński K, Polish J Environ Stu., 2005, 14(3), 281-285.

16. Long R Q and Yang R T, J Am Chem Soc., 2001, 123, 2058-2059.

17. Lu C S and Chiu H S, Chem Eng Sci, 2006, 61, 138-145.

18. Langmuir I, J Am Chem Soc., 1918, 40, 1361-1403.

19. Ehrampoush M H, Ghanizadeh Gh and Ghaneian M T, Iran J Environ Health Sci Eng., 2011, 8(2), 101-108. 
20. Moussavi G R and Khosravi R, J Hazard Mater.., 2010, 183, 724-730.

21. Hong S, Wen C, He J, Gan F and Ho Y S, Hazard Mater., 2009, 167, 630-633.

22. Baccar R, Bouzid J, Feki M and Montiel A, J Hazard Mater., 2009, 162, 1522-1529.

23. Garg V K, Gupta R, Yadav AB and Kumar R, Bioresour Technol., 2003, 89, 121-124.

24. Ho Y S, Porter J F and Mckay G, Water Air Soil Pollut., 2002, 141, 1-33.

25. Rajoriya R K, Prasad B, Mishra I M and Wasewar K L, Chem Biochem Eng Q, 2007, 21(3), 219-226.

26. Shahryari Z, Soltani Goharrizi A. and Azadi M, Int J Water Res Environ Eng., 2010, 2(2), 16-28.

27. Mishra A K, Arockiadoss T and Ramaprabhu S, Chem Eng J., 2010, 162, 1026-1034.

28. Qu S, Huang F, Yu h, Chenc G and Kong J, J Hazard Mater, 2008, 160, 643-647.

29. Wu C H, J Hazard Mater., 2007, 144, 93-100.

30. Luo P, Zhao Y, Zhang B, Liu J, Yang Y and Liu J, Water Res., 2010, 44, 1489-1497.

31. Gomez V, Larrechi M S and Callao M P, Chemosphere, 2007, 69, 1151-1158.

32. Sharma Y C, Upadhyay S N and Gode F, J Appl Sci Environ Sanitation, 2009, 4(1), 21-28.

33. Tor A and Cengeloglu Y, J Hazard. Mater., 2006, 138(2), 409-415.

34. Macedo J S, Junior N B C, Almeida L E, Vieira E F S, Cestari A R, Gimenez I F, Carreno N LV and Barreto L S, J Colloid Interface Sci., 2006, 298(2), 515-522.

35. Mall I D, Srivastava V C, Agarwal N K and Mishra I M, Chemosphere, 2005, 61, 492-501.

36. Gholami-Borujeni F, Mahvi A H, Naseri S, Faramarzi M A, Nabizadeh R and Alimohammadi M, Res J Chem Environ., 2011, 15(2), 217. 


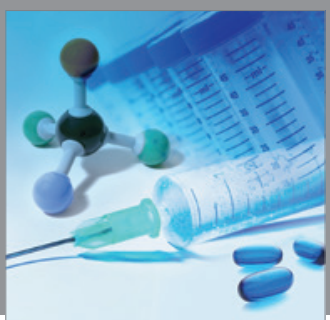

International Journal of

Medicinal Chemistry

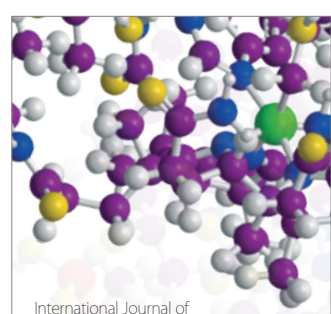

Carbohydrate Chemistry

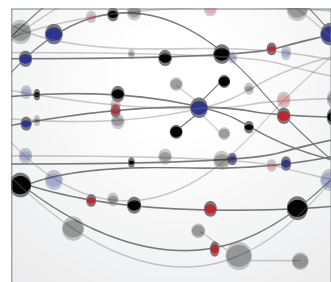

The Scientific World Journal
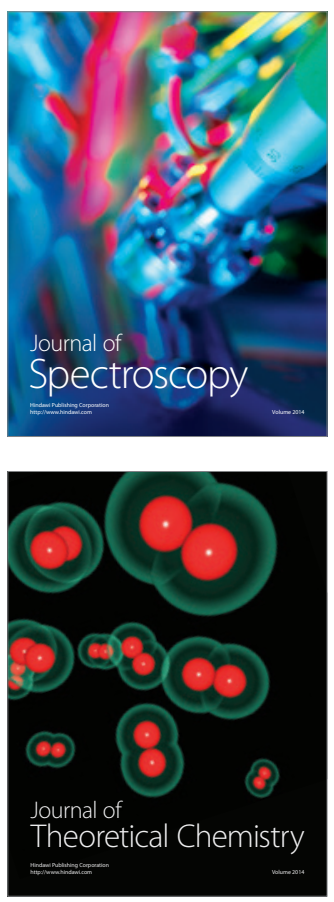
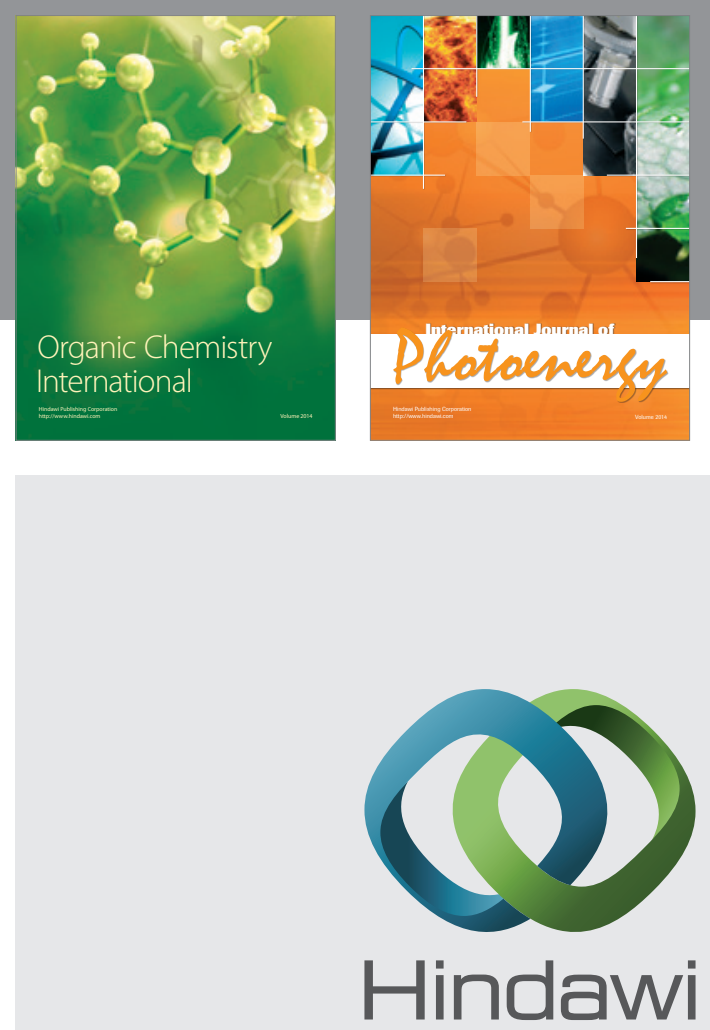

Submit your manuscripts at

http://www.hindawi.com
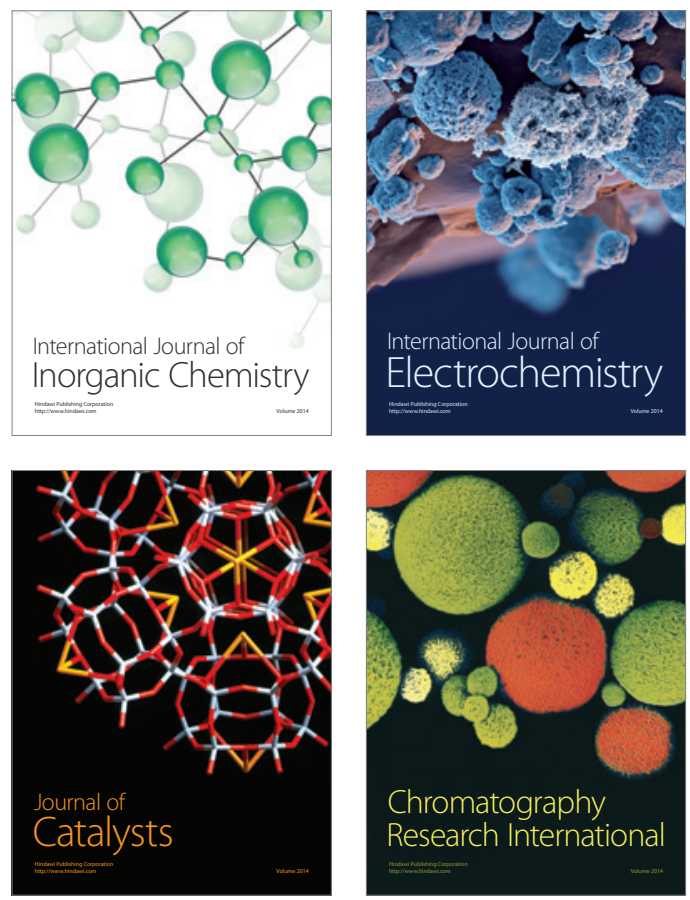
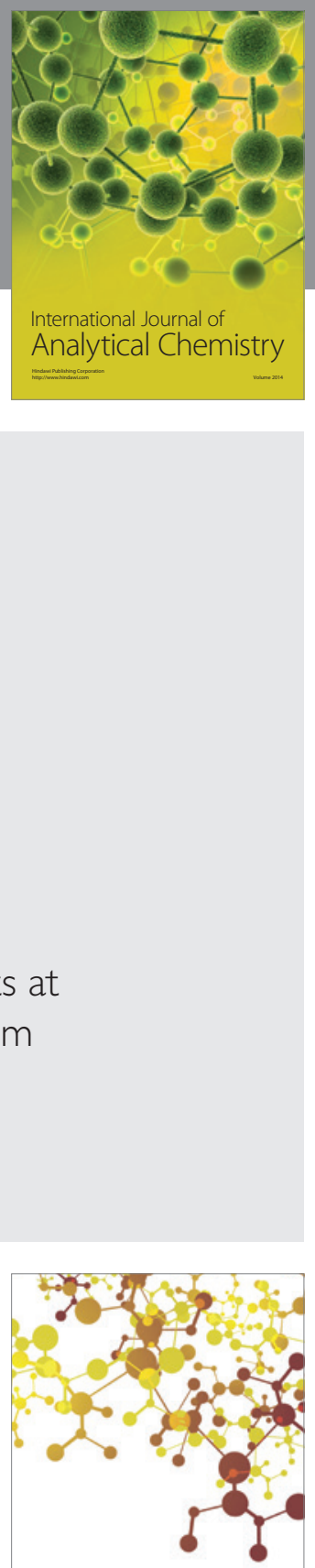

Journal of

Applied Chemistry
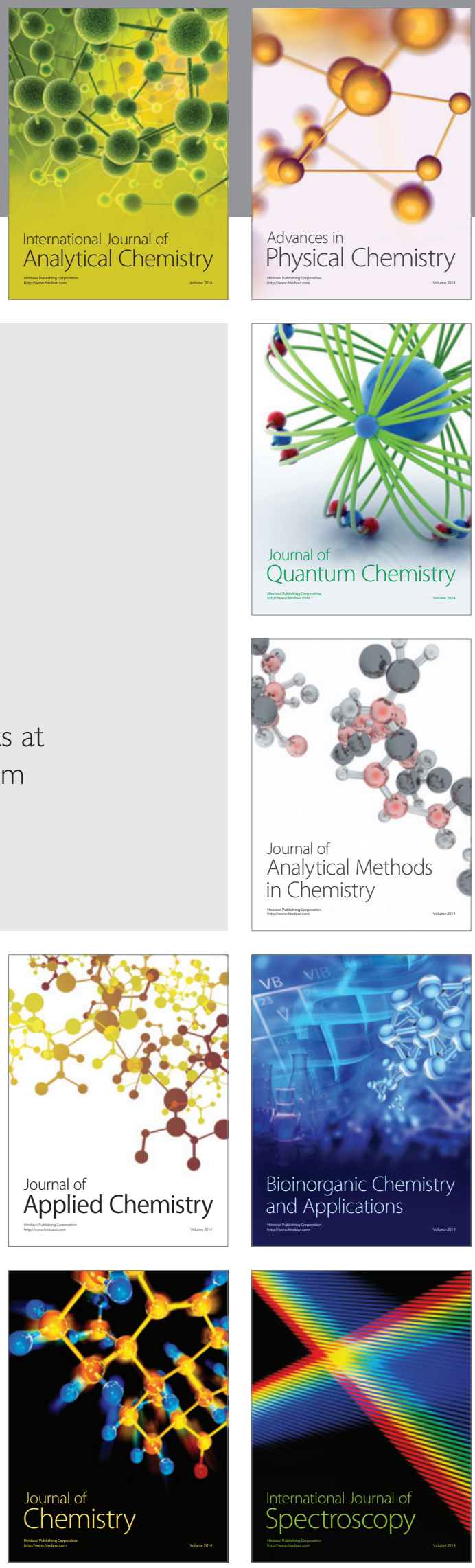